\title{
Islamism as Threat Factor to Construction and Operation Safety of Nuclear Power Facilities
}

\author{
A.N. Nedorubov, N.I. Lobkovskaya* ${ }^{*}$ E.L. Lokonova, and Yu.A. Lupinogina \\ Volgodonsk Engineering Technical Institute the branch of National Research Nuclear University \\ "MEPhI", Lenin St., 73/94, 347360 Volgodonsk, Russia
}

\begin{abstract}
The paper discusses the hazards of construction and operation of nuclear power facilities in Islamic countries or countries with a predominantly Muslim population that is ambiguous about the development of the nuclear industry in their countries. The analysis shows the issue from the point of view of traditional societies and from the position of the leading countries of the world atomic energy and allows us to highlight the most significant and specific features of the stated problem. The analysis shows the issue from the point of view of traditional societies and from the position of the leading countries of the world nuclear energy and allows us to highlight the most significant and specific features of the stated problem. The conclusion is made about the situational and personal nature of the Muslim community life organization and the dominant role of the authoritative religious and community leaders' personal opinion in solving issues not related to spiritual life. Leaders in the field of nuclear energy have to discern into the essence of the signs, reasons and development directions of religious factors in these states, and as the Islamic world is a significant geopolitical factor in the entire system of international relations, its interests and Islamist position cannot but take into account the world political forces promoting nuclear power.
\end{abstract}

\section{Introduction}

One of the major factors in the safe use of nuclear power plants in the 21 st century is the social cultural conditions of the design, construction and operation of these economically and geopolitically significant facilities. The factor of the religious component, which was previously paid little attention, is gaining great importance for the safe operation of such a complex and science-intensive facility as a nuclear power plant despite the post-industrial nature of the nuclear energy field.

In Muslim countries the system-forming characteristic of Islam is the unification of coreligionists and the desire to nourish the sources of faith. There is no doubt that there are forces actively using Islamic vocabulary on this path for their own economic and political purposes. Not only peaceful religious methods of political struggle are practiced but also aggressive methods that restrain the Islamic world on the path of scientific and technological progress. We are talking about Islamism or political Islam when making

\footnotetext{
* Corresponding author: nadezhda-lobkovskaya@yandex.ru
} 
decisions on the construction and operation of nuclear power facilities. Several aspects can be conditionally distinguished in the content of this problem (Fig. 1).

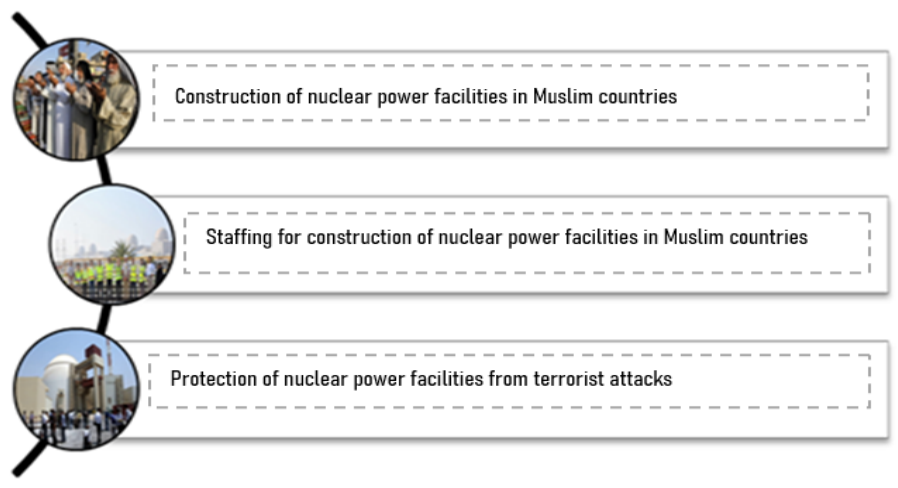

Fig. 1. The main problems of nuclear energy development in Islamic countries

\section{Materials and Methods}

The paper analyzes the press of Muslim (Malaysia, Indonesia), Western European (France, Belgium, Great Britain) countries and the USA. The conducted analysis highlights the problem from the point of view of traditional societies and from the position of the leading countries of the world nuclear energy.

A comparative approach when comparing analytical reviews of leading experts in this field allows us to highlight the most significant and specific features of the stated problem. While Western energy specialists who bring "light" to Muslim countries are rationally oriented, the leaders of the Islamic society relate the solution of such issues to the traditional way of society life and the requirements of Sharia.

It is necessary to immerse yourself in the social and cultural environment of the Islamic world with its features and differences from the technogenically standardized Western one for deeper understanding of the issue. This method of immersion shows the situational and personal nature of Muslim community way of life where traditional and religious morality are priority.

The behavioral method makes it possible to accentuate the causal component of the organization of energy activities in Muslim countries where the role of the personal opinion of authoritative religious and community leaders comes to the fore even when solving issues not related to spiritual life.

\section{Results and Discussion}

The first aspect of the subject under consideration is the issue of nuclear power facility construction in the Islamic countries or in countries with a predominant Muslim population having a mixed attitude toward the nuclear industry development in their countries. [1]. At present Muslims make up 24\% of the world's population and they are representatives of a special Islamic civilization. At present Muslims make up $24 \%$ of the world's population and they are representatives of a special Islamic civilization. The bulk of Muslims live in Central and East Asia (59\%) as well as in the Middle East and North Africa (21\%). The Islamic area of residence covers virtually the entire eastern hemisphere from the Atlantic to the East of China, Indochina and the Sunda Islands. According to various estimates, the number of Muslims in the world exceeds 1.8 billion people. [2] It should be taken into 
account that a significant trend in global development is a surge in population growth in Muslim countries. According to published data from the report of the US research agency "Pew Research Center" the number of Muslims increased to 1.6 billion by 2010 pushing this religion into second place after Christianity. [3]. Taking into account the dynamics of the growth of these beliefs representatives by 2050 their number will actually equalize, and will amount to about 2.6 billion followers of Christian confessions and 2.3 billion representatives of Islam.

At the beginning of 2020 there are 419 nuclear reactors in operation in the world, but only 6 of them are located in Islamic countries, which is only $1.5 \%$ of the total. They are Pakistan having 2 nuclear power plants (Changsha has four reactors and Karachi has one reactor) and Iran (Bushehr has one reactor). At the moment 10 more reactors are under construction. Two reactors are being built by the Chinese state-owned company CNNC in Pakistan, four are being constructed by the Korean company KEPCO in the UAE. There are two reactors in Bangladesh and one each in Iran and Turkey, all four reactors are being built by the Russian State Corporation "Rosatom". [4]

These Islamic states faced many challenges in the beginning of design and construction. In addition to financial, scientific and technical problems, there may be another important one - religious. An example is Indonesia, the largest Muslim country in the world. The issue of creating nuclear power plants has been actively studied by the Indonesian authorities since 1997. In July 2006 a fundamental decision was made in favor of nuclear energy development. According to the government program, it was planned to build four nuclear power plants by 2025 with a total electrical capacity of at least $4 \mathrm{GW}$; the contractors for the construction were to be the American companies Westinghouse and General Electric. [5]

However, a turning point occurred in the Indonesian city of Japara a year later, $09 / 01 / 2007$. Here, at the headquarters of Nahdlatul-ulam, thousands of people gathered to express their interest in the two-day gathering inside the headquarters of this largest traditionalist religious organization with over 30 million members. More than one hundred regional Islamic religious leaders took part in public hearings on the construction of 4 units of the Balong nuclear power plant on the Muria Peninsula. Islamic legal scholars listened to government ministers, senior officials, academics, lawyers, sociologists and activists advocating for and against the Indonesian government's plan. After a dispute between supporters and opponents the assembled ulama withdrew to consider the issue from the point of view of Islamic religious jurisprudence and to deliver a verdict. [6]

In the afternoon of the next day (09/02/2007) a spokesman of these hearings organizers announced at the press conference that a meeting of religious experts on the Muria nuclear power plant had reached the strongest conclusion against the government's plan determining that the proposal referred to the haram, that is, it was forbidden by Islamic law. The news spread around the world during the day. The media and professional news agencies of the nuclear industry in Indonesia, the United States and Australia reported that Indonesian Islamic leaders had issued a fatwa condemning the construction of a nuclear power plant.

Fatwa issuance is a formal response within the framework of religious jurisprudence given by an authority figure (organization) whose task is to preserve the dominant role of the Koran but at the same time to formulate specific responsibilities in a practical way. The confusion of the atomic lobbyists was quite understandable as the issuance of a fatwa was of great importance in three completely different planes.

Firstly, the decision marked the public rallying of a powerful opposition network to the plans of the Indonesian government, which united the country's dominant religious community with other local civic, business and political groups and strengthened them with influence linking village activists to the salons of Jakarta politics. 
Secondly, a mass organization of non-radical Islam spoke out authoritatively on the issue of nuclear energy for the first time in the world.

Thirdly, the Nahdlatul-ulam initiative became an important milestone in the creative use of classical Islamic jurisprudence or fiqh for a responsible and constructive solution of acute social problems of the Muslim community as part of the process of Islam cultural renewal in Indonesia.

The meeting of the ulama began with the expression of opinions after listening to expert arguments before moving on to the main business, the study of the relevant statements in the Quran and Sunnah (sayings of the prophet recorded in the hadith) as well as the principles and precedents in the accredited texts of jurisprudence. As the decision of the Muslim qadis was to be of great importance for a wide circle of the Indonesian Islamic community, much depended on the specific scope of this fatwa beginning from the issue of nuclear energy in general to the proposal for this nuclear power plant in particular. It would be even more dependent on the rationale and references cited in support of this decision in the world of Islamic jurisprudence. Experts in religious law mentioned both positive and negative aspects of the issue of the nuclear power plant constructing in the resolution. The long-term safe disposal and storage of radioactive waste was the first negative issue, followed by concerns about the potential local and regional environmental impacts of the plant, for instance exposure to heated cooling water in local fishing grounds.

Another issue raised was the lack of financial clarity regarding the project and, in particular, referring to future potential costs, especially if the project would be based on an assembly model. In the long term this will leave Indonesia with the old nuclear power plant and then the country will have to pay the costs of decommissioning it.

The last negative aspect mentioned in the decision stemmed from nationalist concerns about external dependence. Nuclear power plant design, operation and maintenance will all be in the hands of foreigners leaving Indonesia a dependent country. Raw materials for nuclear power will require enrichment, and Indonesia has only a small uranium mine with low-grade ore. If, like Iran, Indonesia tries to enrich uranium itself without the proliferation of nuclear weapons, then it will become a competitor to the West as a developing country, while always depending on foreign uranium producers.

Despite these negative consequences three positive aspects were also mentioned: the potential contribution of nuclear power plants to solving the problem of the country's energy crisis; hypothetical contribution to limiting global warming; predicted contribution to the reduction of electricity costs. Each was followed by a short denial, and the arguments of the National Energy Council of Indonesia were not taken into account, since they were not convinced, for example, of a more favorable cost of nuclear electricity.

The creators of the fatwa based their main argument about nuclear energy in the classical tradition of Islamic jurisprudence, which emphasizes a hierarchy of needs in public interest disputes. They were fully correlated within the cultural and religious tradition of the validity of needs in Islamic law. In a summary of their decision regarding the Muriya nuclear power plant, when answering a question about responsibility for the welfare of society, they stated that both the government and the people are obliged to stop the development of nuclear energy in the country.

Some kadis spoke out strongly in favor of the proposal to build a power plant in Muria, but there were few of them. Some of the meeting participants wanted to take the middle ground, but the final result was clear. As Nuruddin Amin, the chairman of the Jepar branch of Nahdlatul-ulama board later explained: "The construction of the Muriya nuclear power plant in Jepar was clearly considered prohibited (haram). Other nuclear energy applications were not discussed by the religious leaders in Jepar." Amin acknowledged that other nuclear power plants can be and can be considered neutral, "maybe nuclear power could benefit the population, agriculture or industry, but we will react negatively." This decision 
was based on the rule that the prohibition of harm or negative consequences should be placed above the benefits or positive consequences: "There are often cases where positive and negative aspects are mixed together. The Quran provides examples of alcohol and gambling, where it is recognized that there can be positive aspects, but according to the Quran, the sin is greater than its benefit. Therefore, they are considered prohibited!" [7]

This fatwa shows the interaction between sacred texts and contemporary social reality. Fiqh has become a tool for modeling a strategically important decision using the Sharia ideals of adopting halal or haram laws (permitted or prohibited), and at the same time a tool for social engineering. Prior to this, there were no precedents for the application of Islamic law on such issues. The issuance of a fatwa testifies to the complexity of this social and cultural factor in the construction of nuclear power facilities in Islamic countries, and it will be impossible not to take it into account.

The second important aspect of the nuclear energy development in Islamic countries is personnel. At the same time, it concerns the replenishment of qualified workers not only at nuclear power plants under construction in Muslim countries but also the work of engineers, operators and operational personnel at the facilities of operating nuclear power plants in non-Islamic countries. The issue of training professional personnel for work at nuclear power facilities in different countries is fundamental already at the stage of forming the basic competencies and skills of future nuclear engineers. [8, 9]

In Islamic countries the staffing of the nuclear industry is dealt with with great difficulty by the governments of countries where the construction of strategically important facilities is taking place. But it must be borne in mind that the employees working there may be subject to various ideological influences, including radical Islamist ones. Not only Asian but also European countries faced a similar problem. In 2014 an incident arose at one of the French nuclear power plants in Nogand-sur-Seine in connection with the admission of an employee who professes Islam to work there. The nuclear power plant in eastern France denied him permission to operate on their territory after he had failed the verification process for reasons they could not disclose.

"This country respects the rule of law, and my client, a qualified person with no criminal record who professes his religion in a natural way like many other French Muslims, would naturally want to know the reasons for this ban," said Sefen Guez, his lawyer. He said that his client had gained access to nuclear facilities in 2012 and 2013, but in March 2014 he had been first denied permission to access the Nogand-sur-Seine power plant following an investigation by the regional police office in Auba. The decision was then overturned in June by a court in neighboring Chalon-en-Champagne. The judge stated that he had had "serious doubts about the legality of this decision," noting that "neither the regional police chief nor the station administration clarified the reason for the denial of access." The engineer had been then allowed to visit the sites again until he was stopped by the leadership of the Nogent-sur-Seine nuclear power plant, who referred to a police chief's order. Police officials said: "it goes without saying that the ban is not based on criteria such as religion or race. Our judgment is based on safety issues." Geuz, a lawyer said he agreed that the police were not required to make their report public, but he stated his client and judge should at least be aware of the reasons for the ban. [10]

Thus, we see another difficult moment for representatives of the Islamic religion to work at the nuclear power facilities.

The third most important aspect of the development of nuclear energy in Muslim countries is directly related to the threat of Islamic radicals. Nuclear power plants become targets of attacks by representatives of banned terrorist radical groups such as ISIS. Since the beginning of the 2010s the Islamist threat has loomed over all of Europe. his was especially acute in countries with a significant cluster of Muslim populations. Using the social and economic "pain points" of society, they easily began to recruit new adepts into 
their ranks, first of all, paying attention to graduates of the universities and already experienced engineers and employees of various corporations. At first, the terrorists planned to attack significant historical sites and events, including the Parisian Eiffel Tower and Louvre, the theater arts festival in Avignon, the international marathon in London, and the Tomorrowland electronic music festival in Belgium. Also, there were planned attacks in bars, markets and attacks on police officers, the purpose of these acts was one to spread fear among ordinary residents. But then they began to set the goal of striking industrial infrastructure including nuclear power plants. [11]

In 2013 French police decoded e-mails between a 29-year-old nuclear power plant worker, Algerian by birth, who had two children and lived in the southern French city of Vaucluse, and the notorious head of AQIM the branch of the Al-Qaeda in the African Maghreb. This supervisor of the group asked him to describe his possibilities for organizing jihad at his place of his residence and work. Ali M., a worker put forward the idea to carry out an attack on the Cadarash nuclear power plant. However, these plans were thwarted. Ali M. proposed to carry out a terrorist attack against ordinary residents in entertainment clubs, in shopping centers and near police stations and municipal institutions. In addition, he proposed to make the main goal of historical and cultural sites and various cultural events of Southern France where thousands of spectators and participants flock to the theater festival in Avignon, which is near the Marcoule Nuclear Power Plant.

After that, his AQIM supervisor suggested him to have special combat training in Algeria. He was to return home and wait for instructions upon completion of the "training". However, having decoded the correspondence in time, the police arrested the Algerian in June 2013. Ali M.'s lawyer stated that his client had been completely brainwashed and that arrest had been a relief for him. [11] This case is by no means an exceptional case. In recent years the problem of radicalization of the inhabitants of Western Europe has tended to expand.

Another example is the incident in Belgium. There were numerous terrorist attacks at the international airport and the Malbec metro station on March 22, 2014. Concerns about nuclear terrorism escalated after Belgian media had reported that the suicide bombers who killed 32 people that day initially had considered attacking the nuclear facility before police that caught a number of suspected accomplices forced them to change targets.

The fact that nuclear power plants were the main targets for terrorist attacks caused a real panic in the media and in society. The Belgian security forces established that the suicide bombers, the Bakraoui brothers, who detonated the bombs in Brussels, had installed video surveillance at the house of the head of the national nuclear program. Video recordings of approaches to the house and routes of movement of the nuclear leader were found in the apartments of the terrorists. The Tianj nuclear power plant was taken under enhanced protection after the explosions in the country.

But it was not the main goal of the terrorists. Their main objective is to build a World Islamic Caliphate including in Europe and Russia. Distraught fanatics are ready to kill everyone who stands in their way, for the sake of establishing the cruelest norms of the orthodox Sharia. They seek to create a nuclear apocalypse. There are more than 150 nuclear reactors in operation requiring enhanced security measures in Europe today. More than 100 thousand people live in a 30-kilometre zone of fifty of them. And the safety of this population is becoming, perhaps, the most important objective for all specialized services, which should pay attention not only to the technical and technological aspects of protection but also to factors such as the social and cultural characteristics of population groups.

Security experts then said that detonating a nuclear reactor was beyond the skills of militant groups, and that the nuclear industry had some vulnerabilities that could be exploited by them. According to Page Stoutland, a head of the NTI independent nuclear 
safety organization, the risk of use by individuals gaining access to sensitive energy infrastructure, including nuclear facilities, is increasing. [12]

In 2014 a strange case of deliberate act of sabotage was recorded at the Belgian nuclear reactor of the Dool 4 power plant. [13]. It was found that one of the officers had contacted with banned groups in Syria. In December of the same year Belgian police traced the movements of a high-ranking official of the country's nuclear industry and his connections with the Islamists who carried out the terrorist attacks in Paris in November 2014, which killed 130 people. As a result, security around the Belgian nuclear power plants has been enhanced.

Industry experts said it would be difficult to deliberately cause a catastrophic nuclear reactor meltdown as there is never one person in the control room. There are usually four to six operators at any time. This, according to Bertrand Barre, a former chief executive of Areva, the Belgian state energy company, reduces the risk of suicide. However, deliberate acts of sabotage cannot be ruled out. In 2014 the Dool 4 reactor was shut down four months after someone deliberately damaged its turbine draining 65,000 liters of oil. The culprit was not found. [13]

The risk of cyberattacks is also increasing. Most nuclear power plants had been built before the advent of the Internet or even the computer age, and their control rooms operate on analogue technology from the 20th century. Nuclear power plants are now rapidly digitizing, according to NTI, increasing the risk that hackers might get hold of the information they are interested in.

The greatest risk is associated with the nuclear fuel cycle, which includes uranium enrichment, fuel production and reprocessing, and transportation and storage of radioactive materials. Experts argue that the pools where the spent nuclear fuel is cooled are more vulnerable than the reactors themselves.

Of particular concern are facilities such as La Hague in France or Sellafield in the UK where spent fuel from dozens of reactors is stored in pools before it is reprocessed or placed in drums for dry storage. Every week plutonium that is one of the two key components of nuclear bombs along with highly enriched uranium is transported overland from La Hague to Marcoule in southern France for processing into mixed oxide fuel.

Experts are also concerned that militants are stealing radioactive materials from medical or industrial facilities. Radioactive isotopes are used in dozens of applications from cancer treatment to pipeline weld inspection, and thousands of packages of small amounts of radioactive material are shipped across Europe every year. Stolen radioactive material from these shipments can be combined with conventional explosives to create a "dirty bomb". [14]

While the radioactivity released by such a device is unlikely to be fatal, it will create tremendous panic and pollute a vast area that will be very difficult to decontaminate. In this regard, it is worth remembering that Chechen fighters installed a radioactive cesium cylinder in a Moscow park in 1995, but they did not blow it up and warned the Russian authorities who managed to deactivate the device.

Since the mid-1990s IAEA Member States have documented more than 3,000 disappearances of radioactive materials. Yukiya Amano, a former IAEA Director General said few of these incidents involve materials that can be used to make a nuclear explosive device but some of the missing materials could be used to develop a dirty bomb. "The fact that there has never been a major terrorist attack using radioactive materials does not mean that it could not have happened," Amano said. [15] 


\section{Conclusions}

The above tendencies in the development of the nuclear industry testify to the fact that deep shocks and major events of modern politics are largely associated with the Muslim world or individual Islamic structures. It forces the leaders in the field of nuclear energy to delve into the essence of the signs, reasons, directions of development of religious factors in these states. As the Islamic world is a significant geopolitical factor of the entire system of international relations and is becoming one of the most important players in world politics, its position and interests cannot be ignored by world political centers.

\section{References}

1. A Muslim Country is Against Nuclear Power Plant Construction, http://www.islamportal.ru/

2. Islam by Country, https://ru.wikipedia.org/

3. M. Lipka, C. Hackett, Why Muslims are the World's Fastest-Growing Religious Group, https://www.pewresearch.org/

4. Nuclear Energy, https://ru.wikipedia.org/

5. Antara, https://www.zol.ru/

6. R. Tanter, Nuclear Fatwa: Islamic Jurisprudence and the Muria Nuclear Power Station Proposal, https://nautilus.org/

7. J. Schiller, Developing Jepara: State and Society in New Order Indonesia (1996)

8. N.I. Lobkovskaya, Modern Education, 1, 32 (2017), http://e-notabene.ru/

9. V.A. Rudenko, Global Nuclear Safety, 1(30), 124 (2019).

10. A muslim engineer, who has been denied access to French nuclear power stations, is to learn at the end of this month whether the decision to bar him will be overturned, his lawyer announced today, http://www.rfi.fr/

11. H. Samuel, Islamist Plot to Blow Up Eiffel Tower, Louvre and Nuclear Power Plant Foiled, Say French Police, https://www.telegraph.co.uk/

12. T. Tamarkin, M. Zahran, The Petro-Islamist Threat: How Fusion Energy Can Save the World, https://fusion4freedom.com/

13. G. De Clercq, Ch. Steitz, Militant Interest in Attacking Nuclear Sites Stirs Concern in Europe, https://www.reuters.com/

14. I.V. Bocharnikov, The Influence of the Islamic Factor on the Nature and Content of Modern International Political Processes, https://nic-pnb.ru/

15. A. Ozharovsky, Yukia Amano: IAEA does not Guarantee Nuclear Safety, https://bellona.ru/ 